\title{
The value of Chinese traditional culture and its influence on moral education in Colleges and Universities
}

\author{
Zhi-quan An ${ }^{1, a}$, Kai Wang ${ }^{1, b,{ }^{*}}$ Peng Lv ${ }^{1, c}$ \\ ${ }^{1}$ Beihua University ,Jilin, China \\ ${ }^{*}$ Corresponding author
}

Abstract: The excellent traditional Chinese culture has rich educational value, especially in the ideological and political education of college students. Excellent traditional Chinese culture and the ideological and political education have the consistent goals, astonishing similarity, so the fusion of the two, sublimation of the ideological and political education through traditional Chinese culture's charm, and the inheritance of traditional Chinese culture will have mutual benefit for the two. In this paper, through the analysis of the value of Chinese culture and the impact of Ideological and political education, it promotes the integration of Chinese excellent traditional culture and ideological and political education, in order to facilitate the development of the two.

Key words: traditional culture; value; moral education

\section{Excellent traditional Chinese culture}

1. The excellent traditional Chinese culture has an important contribution to the development of human beings.

Since the Chinese history could be textually researched to the Ming and Qing Dynasties, the development history of China represents the most advanced level of the world humans' development from the gradual evolution of Chinese characters to various forms of arts blooming, from the Four Great Inventions to the imperial examination system, from the Silk Road to Zheng He's Expedition to the West later on. The history displayes many examples that the great traditional Chinese culture have made great contributions to mankind. It is not only the unique creation of China, but also the representation of core spirit of Eastern and Western civilizations. The excellent traditional Chinese culture has left a great length and thick and heavy colour traces in the history of mankind, it is the common esteem that all mankind enjoy, and the invaluable asset that Chinese people take for pride.

2. The excellent traditional Chinese culture has the position of coordinate

Firstly, filial piety, loyalty, faith, courtesy, righteousness, integrity and the sense of shame are the Eight Virtues that human nature has identified and will not be shaken in traditional Chinese culture even if times and world change. All the time in the history they have a profound impact on people's behaviors. They can be said to be the basic elements of human communication, just like the air is essential to the survival of human beings, but not to be noticed. Secondly, the doctrine of the mean embodies the spirit of great harmony, it is the goal that mankind pursuit for a long term. Today's theme of peace and development is the beautiful dream that humans persistently pursuit. While the ecological civilization thought of landscape nostalgia and Taoism follows nature is respected by all the countries in the world, and is still the scientific concept of the world.

3. The Excellent traditional Chinese culture has a unique cultural form

The excellent traditional Chinese culture has numerous and vivid cultural forms and carriers, elegant such as works of all classes of authors, dulcimer music of lofty mountains and flowing water, ink marks of Lanting Preface, and populist such as yangko dance and firecrackers, lion dance and acrobatics. Their distinctive and unique color and vitality have an indelible impact on human beings, and have rooted in the human blood. Now with the progress of times and the development 
of science and technology, many of the traditional folk cultures and festival traditions are facing fade and alienation, but even for Peking Opera that is difficult to appreciate or dragon and lion dance that is difficult to operate, when they appear in front of people, people will naturally generate resonance from self blood.

4. The excellent traditional Chinese culture represents the peaceful features of Eastern Religions

In traditional Chinese culture, religion plays a very important role in China, Confucianism, Taoism and Buddhism were together discussed in the period of Wu Emperor in North Zhou Dynasty, till now Confucianism has got a stable status, Taoism gradually rises, Buddhism advocates Tianzhu, discuss from difficulty gradually to harmony. The three thoughts are different, but the cores are the same, they all make people tend to kindness with slightly difference, but without affecting the whole. Chinese religion emphasizes benevolence, kindness, and harmony, which is widely divergent from Western religious thought of God's destruction, or killing infidels. And this is also an important part of Chinese traditional culture.

5. The excellent traditional Chinese culture has a strong inclusivity

The traditional Chinese culture is not content with staying changeless like fossil culture. Throughout history, it is not difficult to find that the history of cultural development in China is in a time of innovation and development, and in the continuous self denial, it actively integrates a variety of excellent foreign culture with a process of scientific fusion. In the history of China, there are several important periods of great national integrations. During this period, the cultures of the minority nationalities were integrated into the Han culture, and finally the present Chinese culture appeared. Since modern times, although China has experienced several major setbacks and serious cultural loss, China's outstanding traditional culture still plays a very strong inclusivity, absorbing excellent cultural factors from all over the world and improving itself to adapt to the era. So that the excellent traditional Chinese culture can be gradually converted to the excellent modern Chinese culture, tending to be complete.

II. The impact of excellent traditional Chinese culture on College Students

In today's society, with the background of science and technology development, a lot of elements of traditional Chinese culture go toward an impasse, regardless of the quintessence of opera, or a variety of traditional festivals, they are gradually fading and alienating because of a variety of reality. Such as the pollution of the environment by fireworks during the Spring Festival, and the fire hazard by burning paper during Tomb-sweeping Day, all these are just a huge dilemma that the important carriers of traditional Chinese culture are facing. But in today's society, people have experienced the painful history of modern times, due to material scarcity, as well as the cultural revolution, our people are suffered from the aspect of spirit to that of objective, and there comes a cultural division. What is more, for the long-term economic backwardness, the national government had to focus on speeding up economic construction, cultural construction and restoration did not receive enough attention, so there is a generally strange sense in the society toward traditional Chinese culture.

However, the contemporary college students as the young elite forces of society, have a wealth of scientific knowledge, and in the long-term learning process, compared to their parents, their grandparents have accepted more influence of traditional Chinese culture. They need to learn more from China's traditional culture than people who are out of school. Indeed, among Chinese young generation they are the backbone of high quality, we can have enough confidence on their professional skills, but in recent years, college students' low quality events are profound to us, all these reveal the deficiencies of the current college students in moral quality, which is an important 
problem to be solved urgently at present, related to the future development of China's foundation.

Luckily nothing is absolute, in fact the current college students' moral quality is uneven, the good and the bad are mixed, at the same time when we see many low quality events, a lot of touching stories that take college students as the protagonist have been staged. And we see a lot of positive stories, most of the main characters have a common feature, filial piety and humility. In the final analysis, the traditional Chinese culture is deeply rooted in their hearts.

In daily life, it is not difficult to find that most of the people who are modest and kind to others are knowledgeable in mind, and these people will have a deeper study on excellent traditional Chinese culture compared to ordinary people. In fact, this phenomenon is particularly evident in this group of college students, college students are the elites left behind by college entrance examination screening, but even in the same university there is a huge difference. Some college students' behaviours, in the university period, like lethargy, excesses, cheating, and spitting are extremely common for themselves while these should make people feel ashamed, and they have no intention to correct them. According to the survey, more than $40 \%$ of college students have the above characteristics. But some students who have a deep understanding of the excellent traditional Chinese culture often own an extremely strong self-discipline ability, silt but don't dye, and have a strong sense of shame. And they are principled and friendly with things and people. According to my investigation on five universities selected among intermediate level colleges, more than $75 \%$ of the college students with the above features have a deep understanding of traditional Chinese culture. Thus, we can see the excellent traditional Chinese culture has a very important impact on college students. In the same university, due to China's college entrance examination system, there are small differences in learning ability and professional technical level, and in this environment the huge differences in personality is due to the influence of traditional Chinese culture on them.

To sum up, in terms of ideological and political education, it can be said to be the one most close to the traditional Chinese culture education. It can be said that both the behaviour principles emphasized by the ideological and political education and the main teaching goals can get invaluable advice in traditional Chinese culture. In fact, in recent years, China's ideological and political education continues to carry out the integration with the Chinese excellent culture, as Marx doctrine in China, which will certainly achieve gratifying results.

Acknowledgement

This paper was supported by Scientific and Technological Planning Project of Beihua University (No.YB201622).

Reference :

[1] Liu Shuxia, the Chinese traditional culture and ideological and political education integration of factual and ideal situation (J), Tangdu journal, 2011 (1).

[2] Li Liang, an analysis of the role of Chinese excellent traditional culture in Ideological and political education in Colleges and universities (J), Journal of Social Sciences of Jiamusi University, $2012(4)$

[3] Chen Shaoping, research on Chinese traditional culture education and ideological and political education in Colleges and universities (J), ideological education research, 2016 (6)

[4] Xiao Zhaoying, on the promotion of Chinese traditional culture in the ideological and political education in Colleges and universities (J), brand, 2015 (2)

[5] Pan Zhijun, the role of Chinese traditional culture in Ideological and political education in Contemporary Colleges and universities (D), Xi'an University of Science And Technology, 2015 
[6] van Miaoran, on the implementation of Chinese traditional culture in the ideological and Political Education (J), modern communication, 2016 (6)

[7] Wang Jirong, the study on the integration of Chinese traditional culture into Ideological and political education in Colleges and universities (J), Journal of Chifeng University, 2016 (21)

[8] Xie Xiaolong, the basic connotation of Chinese traditional culture and its application in Higher Education (J), Inner Mongolia TV University Journal, 2017 (1) 